\title{
Multidisciplinary approach for assessment of the factors affecting geohazard in karst valley: the case study of Gravina di Petruscio (Apulia, South Italy)
}

\author{
Gioacchino Francesco Andriani ${ }^{1}[1] \cdot$ Lidia Loiotine $^{1,2}$
}

Received: 12 December 2019 / Accepted: 14 September 2020 / Published online: 25 September 2020

(c) The Author(s) 2020

\begin{abstract}
Management plans, actions and strategies for preventing and mitigating natural disasters require detailed information on natural and human-induced geohazards for the area under evaluation. Karst areas are particularly prone to instability due to the natural fragility of their environment but are also vulnerable due to human activity. In-depth studies of the factors controlling mass movement processes, including land use over time, become crucial for understanding instability mechanisms and future landscape evolution, as well as for designing preventive measures and control techniques. The Murge area, in the central part of Apulia (South Italy), is crossed by a vast network of dry valleys, locally named lame and gravine, whose morphology may resemble the most well-known canyons and gorges of the world. The genesis of these dry valleys is controversial and still the subject of continued debate, although their origin is directly related to the geostructural setting and the uplift of the Apulia foreland since the middle Pleistocene. Each of these karst valleys has particular morphometric characteristics as well as their own morpho-evolutionary history strongly linked to the different types of fault or fracture on which they developed. Also, geological and geotechnical characteristics of the rock substrate channel, and historic humanmade slope excavation or remodeling play an important role. Unfortunately, several tragic events which occurred during the last decades have shown the susceptibility of the Apulian dry valleys to natural hazards, sometimes caused by human activities. This paper proposes, by means of a case study on a dry valley called Gravina di Petruscio in the Arco Ionico Tarantino subregion, a multidisciplinary approach using traditional methods of investigation and combining results to arrive at a critical appraisal of information that are suitable for a geohazard susceptibility analysis in karst environments. Geological, geostructural and geomechanical surveys, together with petrographic observations in thin sections of the outcropping materials, allow to understand the genesis of the valley and then its evolution mainly due to slope retreat processes. Both sides of the valley have been found to be affected by planar slides, wedge slides, direct toppling and falls, while the caves, mostly modified by humans, are affected by thinning, spalling and crushing of pillars, and partial or total collapse of cave roofs. The predisposing and triggering factors of the most common mass movements are presented and discussed. Mitigation and prevention measures for future planning, and remedial engineering structures are reported.
\end{abstract}

Keywords Geohazard $\cdot$ Karst valleys $\cdot$ Slope failure $\cdot$ Protection

\section{Introduction}

Gioacchino Francesco Andriani

gioacchinofrancesco.andriani@uniba.it

Lidia Loiotine

lidia.loiotine@uniba.it; lidia.loiotine@unil.ch

1 Dipartimento di Scienze della Terra e Geoambientali, Università degli Studi di Bari ALDO MORO, via E. Orabona, 4, 70125 Bari, Italy

2 Institut des Sciences de la Terre, Université de Lausanne, Géopolis, CH-1015 Lausanne, Switzerland
In the last 2 decades there has been a significant increase in tourism at the largest canyons and gorges of the world, for example the Grand Canyon (Arizona), the Colca Canyon (Perù), the Fish River Canyon (Namibia) and the Copper Canyon (Mexico), to name a few. At the same time, canyons and gorges are prone to hydro-meteorological and geologic hazards, as demonstrated in recent years by an increase in damage, disasters and deaths due to both human-made and natural factors (Lacasse and Nadim 2009). 
According to Goudie (2004), a canyon is formed by running water and is a long, deep, relatively narrow, steepsided valley, often cut through bedrock, which forms precipitous cliffs along the valley walls. Morphostructures of smaller dimensions, but with steeper walls, are called gorges and ravines, although the terms do not have a single meaning in the specific literature. Marković et al. (2003) and Božić and Tomić (2015) distinguish gorges from canyons on the basis of geometric factors, namely the ratio between depth (H) and width (D) and inclination of the valley sides. Thus, in summary, they state that canyons are deeper and with more inclined sides than gorges which are as deep as half of their width and have about $45^{\circ}$ inclined slopes. Regarding the distinction between ravines and gorges, Goudie (2004) reports that ravines are structures of minor order, wide and deep up to some tens of meters, with flat bottoms, and they develop on surficial or degraded deposits.

The genesis of canyons and gorges can be attributed to the incision of a river on an uplifting block, to the superimposition of a stream on resistant rock, to the surficial water circulation and/or to a waterfall retreat (Rashleigh 1935; Derricourt 1976; Tinkler et al. 1994; Van der Beek et al. 2001). Larger gorges could be structurally governed by regional fractures and faults (Scheidegger and Hantke, 1994).

Similar morphostructures can be found in the Apulian karst landscape of Southern Italy and, more precisely, in the Murge area. Here, an emerged block of the Apulian foreland constituted by a large plateau trending in a NW-SE direction, is made up of a $3 \mathrm{~km}$ thick Cretaceous carbonate succession overlain in places by thin deposits of Plio-Quaternary calcarenites and carbonate sands and clays (Pieri 1980; Ciaranfi et al. 1988). The Murge area is a terraced tableland in which the karst landscape develops in the form of karrens, dolines, polje, uvalas and dry valleys, although the latter are not strictly related to karst activities (De Waele et al. 2011; Parise 2011). In particular, a wide network of stream valleys crosses the whole territory and links the areas of higher structural relief to the Adriatic and Ionic coastal plains. These morphostructures are incisions in the Plio-Pleistocene and/or Cretaceous carbonate rocks, whose morphology resembles canyons and gorges, although they do not exceed $5 \mathrm{~km}$ of length, $120 \mathrm{~m}$ of width and $50 \mathrm{~m}$ of depth (Mastronuzzi and Sansò 2002), and are locally referred to by the terms: lame and gravine. These morphostructures, many of them designated as protected areas for their historic and landscape value, are dry today and show an ephemeral stream only during particularly intense meteorological events. Actually, there are numerous canyons and gorges formed on carbonate rocks, located in Europe, Asia and Africa that, except for bigger dimensions, show similar features to lame and gravine. The origin of these morphostructures is related mainly to tectonic uplift which induces an increase in fluvial down cutting (Li et al. 1995; Stokes and Mather 2008; Doğan and Koçyiğit 2018).

Lame and gravine in the Apulian karst environment are highly susceptible to natural hazards, such as floods and slope instabilities (Parise 2007; Andriani and Walsh 2009). In fact, during intense, short-lived rainfalls, surface runoff waters flow towards the sea through these valleys, sometimes overflowing and causing severe floods. According to Day (2007), "flooding of the karst landscape is an integral component of the natural karst hydrology" and it is often caused by heavy or prolonged rainfalls, thus the epikarstic infiltration capacity is exceeded by the overland flow. Recent examples of such events occurred both along the Adriatic side of Apulia (Bari and its neighbouring towns in October 2005) and the Ionian coast (Gravina di Grottaglie in 2006), and the hilly border of the Murge area (Gravina di Ginosa in 2013). These derived from naturally occurring processes and human-made activities, closely related to the geology, hydrology and climate of the specific subregion. It is no coincidence that both natural and human-induced hazards in karst terrains have increased dramatically over the last two centuries. This is mainly due to climate change and increase in population and reflect human capability to produce irreversible landscape damages (White 1988; Gams et al. 1993; Williams 1993; Nicod et al. 1997; Akdim and Amyay 1999; Burri et al. 1999; Urich 2002; Parise and Pascali 2003; Bonacci 2004; Calò and Parise 2006; Sauro 2006; Parise and Gunn 2007; De Waele et al. 2011). As a result, urbanization, stone clearing, deforestation and uncontrolled quarrying in catchment basins have increasingly transformed and partially or totally destroyed the karst landscape, also causing deterioration in the quality of groundwater. The negative results consisted of an overall modification of valley morphology, surficial and underground drainage, vegetation and soil characteristics, thus changing the drainage network and water infiltration rates, and natural flood control of this area (Sauro 1993; Smith 1993; Frumkin 1999; Ginès 1999; Kacaroglu 1999; De Waele and Follesa 2004; Spizzico et al. 2005; Delle Rose et al. 2007; Gunn 2007; Andriani and Walsh 2009). In spite of all this tangible evidence, flooding is still an underestimated hazard in Apulian karst environments despite being relatively widespread. In addition, gravine are on average deeper than lame and characterized by steep sides, with overhanging or subvertical walls and terraced profiles. Various discontinuities in the rock masses such as joints, faults, fractures, voids or conduits enlarged by aqueous solutions and human-made caves constitute predisposing factors for gravitational instability processes. The latter in the Apulian gravine represent a serious hazard that may cause significant economic losses and deaths. For example, it can be proposed that the collapse of a twostory building and a road on January 21, 2014 in the historic center of Ginosa, was caused by a sudden failure of a cavity 
roof located close to the orographic right side of the Gravina di Ginosa. Gravine and lame are, in fact, characterized along their slopes by numerous caves of both natural and anthropogenic origin and while the first seem partially or totally unaltered, the latter were dug and deeply modified by the local people who initiated these activities using the existing system of rock discontinuities. In ancient times, the caves have been used as shelters from harsh temperatures and barbarian invasions and, with time, their inhabitants learned to exploit the rocks that, especially in the case of calcarenites, were easy to excavate and work. In a subsequent phase, in fact, the cavities were enlarged and adapted to rupestrian life, until they became real settlements and places of worship during the Middle Ages (Serafini and Di Giorgio 2018). Some examples are the rock settlements in the gravine of Ginosa, Grottaglie, Massafra and Mottola (Apulia), and Matera (Basilicata), where the presence of karst and humanmade cavities constitute an important susceptibility factor in developing landslides or sinkhole collapse on the terraced slopes (Fig. 1). In fact, natural caves in karst environments also represent an element of inherent instability. They form and slowly migrate upward depending on hydrologic conditions until they reach the ground surface and cause sinkholes due to progressive roof failures and/or pillar and wall crushing (Waltham and Lu 2007; Parise 2011). In many cases, such situations take place after intense rainfall which creates conditions favoring rock mass weakening due to softening induced by water infiltration, a circumstance that occurs especially in the presence of calcarenite rocks.

To minimize the degradation of this fragile environment, the damage to natural resources and cultural heritages and the loss of human life and property, the community, over the years, favored the approval of several laws. Thanks to these laws, gravine and lame are subjected to legal landscape conservation. Any action that would disturb their natural, morphologic and historical-cultural background (i.e., excavations, land use modifications and soil or rock removal) is forbidden. Hydraulic and vegetation improvements and decontamination interventions, with natural engineering techniques, are strongly promoted. The aim of these remedial actions would be to reduce human impact and to restore the environment in these morphostructures, thus avoiding potentially dangerous landslides and floods.

The results of a study on Gravina di Petruscio, one of the gravine of the Apulian Murge area, are reported here to present a multidisciplinary approach including on-site geologic, morphologic, geostructural and geomechanical surveys, and petrographic analyses, indispensable for providing the framework for a geohazard assessment. In the particular case of Gravina di Petruscio, this approach has allowed us to give a qualitative assessment of slope stability, classify the modes of movements that occurred over time and define the predisposing and triggering factors, both natural and anthropogenic. Furthermore, new hypothesis about the genesis of Gravina di Petruscio and information about historical human impact have provided important insights into the morphologic evolution of the valley, in the past, present and potentially in the future. Thus, the information collected has been useful for assessing the actual degree of mass movement susceptibility affecting the valleys, defining priorities for management prevention and engineering interventions, and providing valuable reference details for further slope stability analyses of unstable rock masses.
Fig. 1 Human-made caves dug into the valley sides of Gravina di Ginosa (Taranto, south Apulia) constitutes a condition highly hazardous to the stability of both the slopes

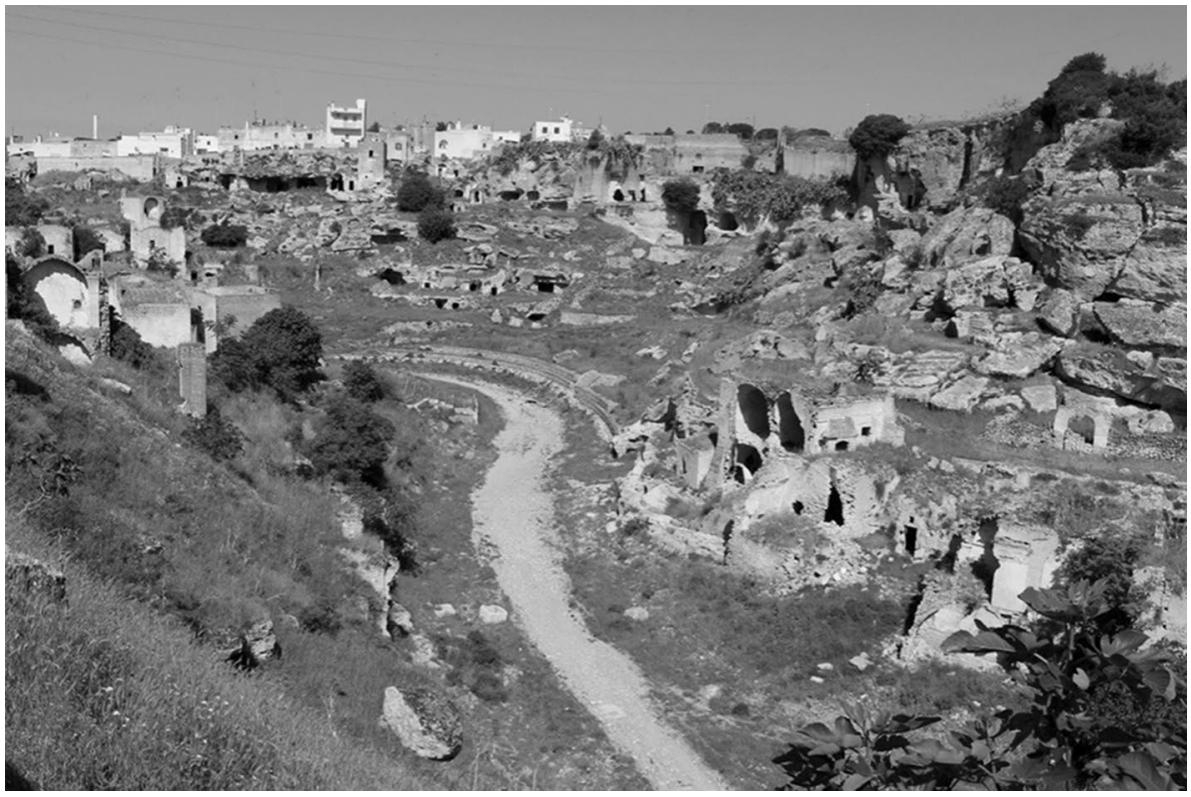




\section{Lame and Gravine}

The term lama (Rohlfs 1976), which translated from Latin lama means "pond", indicates slightly cut valleys, with flat bottoms, inside which the water flows only during and after considerable rains. The etymology of the term gravina derives from the Celtic grava, which means "well" or "hole", and from the Messapian term graba, which indicates, instead, erosion of riverbanks. Gravina has the same etymological root of many other terms used in the Apulian karst nomenclature: grave, gravaglione and gravinelle. To these terms is associated the concept of depth, the main morphometric element that distinguishes gravine from lame (Parise et al. 2003).

The genesis of lame and gravine is still a subject of debate. In the past, numerous studies have been carried out on these morphostructures (Colamonico 1953; Neboit 1975; Parenzan 1988), but a unique theory about their origin has not yet been formulated. According to the theories of De Giorgi (1884) and Segre (1947), these morphostructures originated by the erosion of the substratum by a watercourse. They can be distinguished depending on their distribution. Lame are characteristic of the Adriatic coast of Apulia, while gravine are located in the Arco Ionico Tarantino. Colamonico (1953) and Palagiano (1965), on the other hand, attribute the different morphology of gravine and lame to the different properties of the substratum. That is, outcroppings of erosive Plio-Pleistocene calcarenites favor steep sided valleys with a V-shaped cross profile (gravine), in contrast to the near verticalsided valleys, with a U-shaped cross-profile, that occur in the more resistant Cretaceous limestones (lame). The literature shows that since the middle Pleistocene, during the tectonic evolution of the southern Apennines thrustbelt, the Apulia foreland has been subjected to a regional uplift with different rates and tilting between the Ionian and the Adriatic sides (Doglioni et al. 1994). The higher rates of uplift, from 0.21 to $0.27 \mathrm{~mm} / \mathrm{yr}$, of the Ionian area, consequently, caused more intense erosive activity due to water flow and a greater development of gravine along the coastline, even though small-size gravine, up to $20 \mathrm{~m}$ deep, are also located, at places, on the Adriatic coast (Belluomini et al. 2002; Parise et al. 2003). Thus, as a result of this recent uplift of the Apulia foreland, their origin could be related to superimposition processes (sensu Bates and Jackson 1987). Moreover, according to Boenzi (2004), their development is linked to the karst nature of the Apulian territory, thus the presence of cavities formed by underground water circulation could have facilitated the deepening of these superimposed morphostructures. Furthermore, Badino (1995) hypothesizes, with regards to gravine, a relationship between rapid deepening of pre-existing stream valleys and solution processes of carbonate rocks due to a local humid microclimate. Parise et al. (2003) list a series of morphologic and geologic elements to justify a different origin of the two types of morphostructures, starting with measured differences in depth and width of the two types of valleys, gravine are deeper and narrower than lame. Mastronuzzi and Sansò (2002) suggest that sapping processes (Baker et al. 1990; Dunne 1990) strongly influenced by Pleistocene sea-level changes had a leading role in the genesis of gravine and subsequently Mastronuzzi (2010) asserts that lame and gravine represent the same morphostructure, but they are differently named in the various areas of Apulia. He recognizes two distinct morphologies of these valleys, based on the transverse profile, to which two different genetic processes are associated. Lame and gravine with a "V" transverse profile have narrow subvertical walls, are deep, up to $100 \mathrm{~m}$, and are eroded into limestones. They can be compared to North American canyons and gorges, and correspond to superposed streams, which tend to deepen in areas subjected to tectonic uplifting, to reach base level. Lame and gravine with a "U"-shaped (or box-like) profile have stepped sides, are up to $40 \mathrm{~m}$ deep and are found in calcarenites. In his opinion, some of these valleys are linked to groundwater sapping processes, as described by Dunne's model (1990).

\section{Study area}

Gravina di Petruscio is located in the Apulian subregion called Arco Ionico Tarantino, an arc-shaped terraced landscape, which extends from the base of the Murge plateau to the Ionian Sea (Fig. 2). It is defined by a succession of gently inclined shelves (marine terraces) limited by escarpments subparallel to the coastline and developed from about $400 \mathrm{~m}$ above sea level down to the current coastline. These terraces are the result of the interaction between the tectonic uplift of the Apulian platform and the glacio-eustatic sea level modifications that occurred since the middle Pleistocene (Ricchetti et al. 1988). A channel network of lame and gravine, in simple catchments and watersheds that are difficult to recognize, cuts the marine terraces and crosses the entire territory terminating upon reaching the sea.

The locally well known Gravina di Petruscio is a valley incised in the Plio-Pleistocene Calcarenite di Gravina Fm. (Tropeano and Sabato 2000). It is located east-southeast of Mottola and about $4 \mathrm{~km}$ long from north to south. The feature terminates at the Palagiano plain, the lower marine terrace just behind the ancient dunes and lagoons of the Ionian coast (Fig. 3). Due to its geologic and morphologic peculiarities, the gravina has been classified as a Geosite, since it belongs to the geological heritage of the Apulia 
Fig. 2 Geographic location of the study area
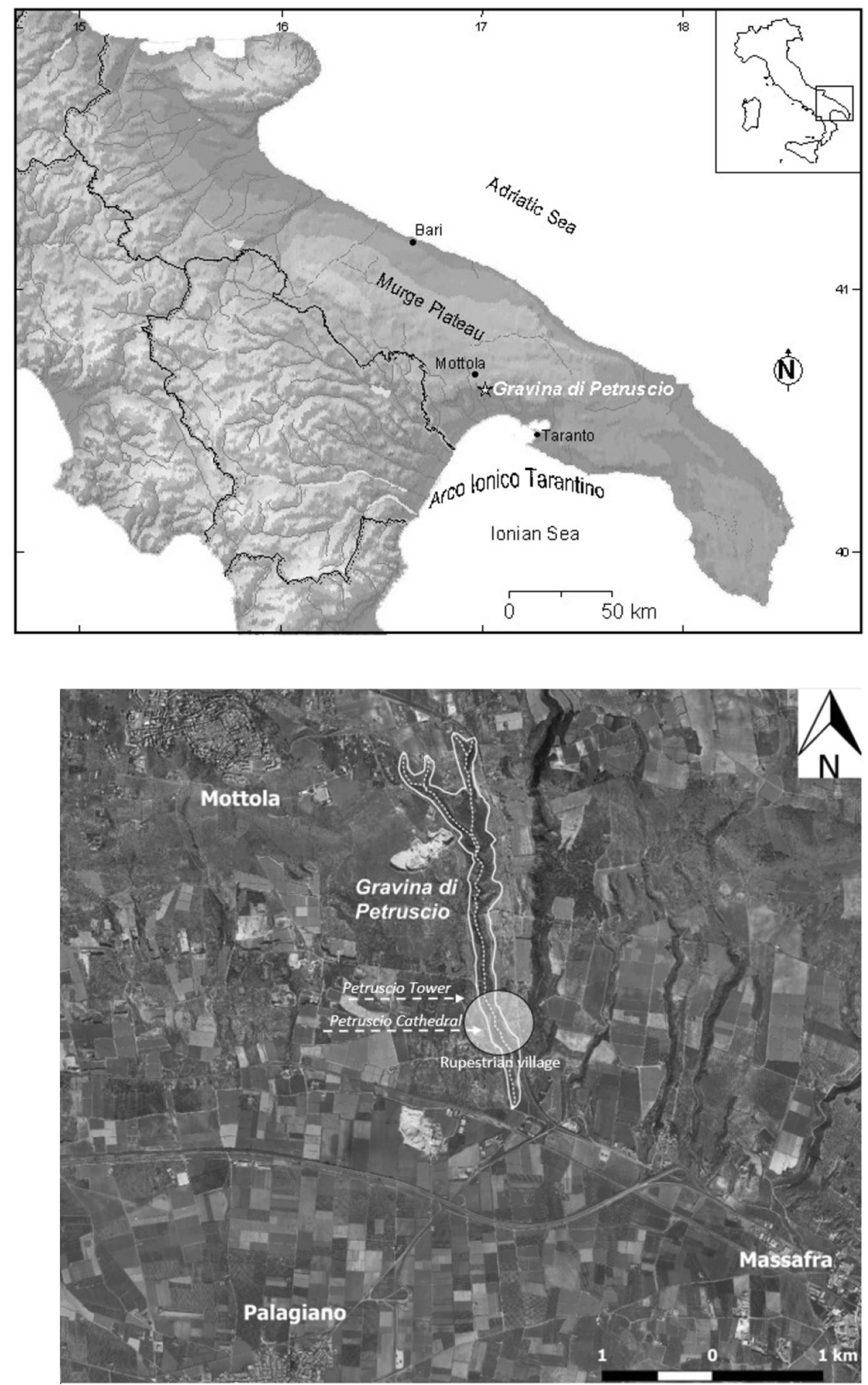

Fig. 3 Gravina di Petruscio shown in an orthophoto excerpt (base map from https://www.sit. puglia.it/; modified)
Region (Regional Law 4 December 2009), and is part of Parco della Terra delle Gravine (Regional Law 20 December 2005). Gravina di Petruscio is subject to protection, since it also falls into the category of "Landscape Asset", or Bene Paesaggistico when translated into Italian. The valley is known for traces of human presence since the Bronze Age. Since ancient times, the natural landscape of the gravina offered a shelter from the cold winds of 
tramontana and barbarian invaders. From these protections, a real rupestrian village was born, as testified by the 200 artificial caves excavated in the calcarenites and distributed along both sides of the valley. In the highest part of the gravina it is possible to see traces of medieval settlements, such as the remains of the perimeter walls of the Petruscio Tower, carriages and drinking troughs. The hypogea are "hive-like", consisting of caves located on several shelves (terraces) and interconnecting with each other. These structures were used for a wide variety of purposes including, housing settlements, agricultural purposes and religious worship. Indeed, it is known that the so-called Cathedral of Petruscio, is an architecturally refined rupestrian church, with a single nave divided by two arched pillars, but with the entrance now hidden by rock blocks fallen from the slope face. The cavities located on the walls of the gravina allowed exposure to the sun in winter and shelter from it in summer. The most recent cavities are characterized by a single quadrangular plan with rectangular entrances which reveal the areas reserved for kitchens, fireplaces and alcoves. Beams and handles, both on the vaults and walls, were used for tying animals and passing ropes to support food supplies. Cavities in the floor were used to store food. Outside there are wells for the accumulation of waste and a series of channels to transport rainwater into specially dug tanks. The last traces of human activity date back to the year 1000 A.D. Currently the reasons for the abandonment of the village are not known, although some researchers believe it is attributable to difficulties with water supply.

\section{Method}

Evaluating geohazards in karst environment is an interesting yet complex problem due to a high degree of uncertainty in the assessment of the factors influencing slope stability and morphologic changes in channels or valleys. It requires the need for a multidisciplinary approach taking into account spatial and cultural information, including geologic and morphologic setting, properties of rocky outcrops, effect of groundwater, karst development and the role of human impact over time. All these factors must be, in advance, identified and then quantified and normalized to be utilized in a geohazard assessment for such a study area. Therefore, for the Gravina di Petruscio site, geologic, morphologic, geostructural, geomechanical and petrographic data were measured using traditional methods and analyzed in a way suitable for the specific problem. As such, it was possible to identify and prioritize the predisposing and triggering factors of the most common mass movements needed to assess potential geohazards, develop mitigation strategies and implement remediation.

\section{Features and results of the research activities}

\section{Geologic and morphologic setting}

The geological framework of Gravina di Petruscio is characterized by an upper Cretaceous succession of mainly calcareous and dolomitic rocks related to a wide carbonate platform (Calcare di Altamura Fm.), on which discontinuous and thin upper Pliocene to lower Pleistocene transgressive calcarenites (Calcarenite di Gravina Fm.) lie. A slight angular unconformity exists between the underlying Mesozoic strata and the overlying Cenozoic deposits. In particular, the Calcarenite di Granite Fm. is mainly composed of packstone or grainstone bio-lithoclastic calcarenites typical of shallow and agitated marine temperate-waters (Ricchetti et al. 1988; Tropeano and Sabato 2000). They are light yellow to pale brown in color and mostly composed of low-Mg calcite (>95\%) with an insoluble residue consisting of mostly clay minerals and negligible quartz, feldspars, gibbsite and goethite. Carbonate cementation is common for all the calcarenite types, although generally poor and irregular, and gives the rocks a strength characteristically typical of soft rocks. These properties are also the main factor influencing the hydraulic properties of this geologic unit (Andriani and Walsh 2003, 2010; Andriani et al. 2013). Outcrops along both sides and in the channel-bed incision of Gravina di Petruscio provide excellent calcarenite exposures, both perpendicular and parallel to depositional strike, and also allow easy access for field observations, measurements and rock sampling. They comprise about $45 \mathrm{~m}$ of a rhythmically bedded sequence of subhorizontal beds and banks (0.6-2.5 m thick) and exhibit normal grading and parallel laminations (Fig. 4). Beds and banks, gently dipping between $3^{\circ}$ and $8^{\circ}$ towards the SW and SE, respectively, on the east and west sides of the fluvial incision, and this demonstrates the important role exerted by tectonic forces in the morphostructural setting of the area. Banks in the lower part of the exposure exhibit microconglomerates and/or calcirudites which grade progressively upward to medium and medium-fine calcarenites. Furthermore, the upper bank, located on the ground surface, in correspondence with the oldest terrace, is covered by calcareous crusts (caliche) up to $5 \mathrm{~mm}$ thick, due to capillary rising processes. No significant deformation affects the entire sequence which appears rather homogeneous and continuous, despite the presence of cavities, faults and fractures, the latter mainly parallel to the slope faces, and in close relationship with the structural asset and stress release failures. 
Fig. 4 View of the orographic right side of Gravina di Petruscio

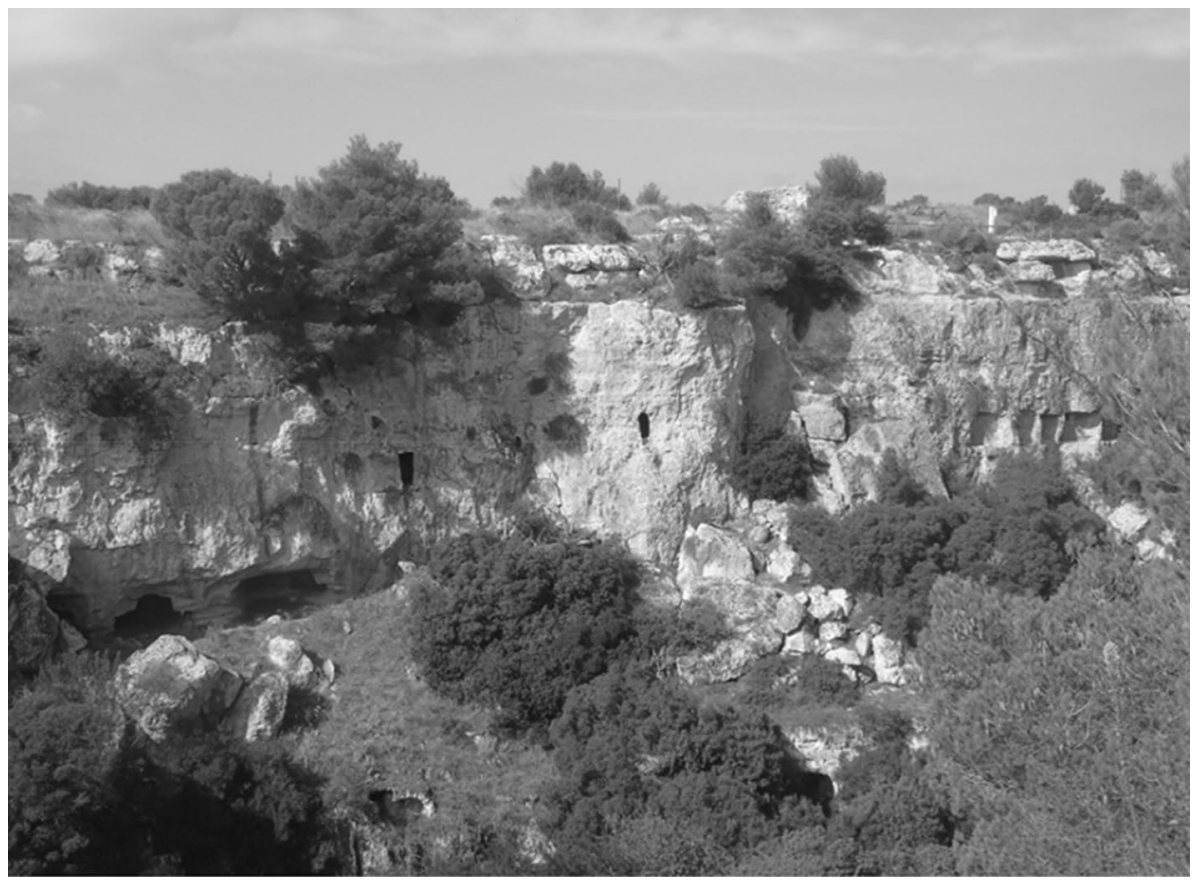

Field observations, facilitated by the presence of fresh rock surfaces due to recent collapses, were accompanied by the collection of representative rock samples to be used for thin section preparation and subsequent petrographic examination. Starting from the bottom, each bank is characterized by rudstones with fine, medium and coarse sub-rounded and sub-angular terrigenous clasts dispersed in a sandy bioclastic matrix. The rudstone clasts originate from the weathering of the Mesozoic carbonate bedrock. Rudstones pass gradationally up into grainstones of high bioclastic content and having grain sizes gradually decreasing upward. The grainstones are rich in lamellibranchs, echinoderms, red algae, serpulids, brachiopods, gastropods and benthic foraminifera, and show an evident lamination highlighted mainly by the parallel grain orientation patterns caused by current transport (Fig. 5). No noteworthy amount of clay or carbonate

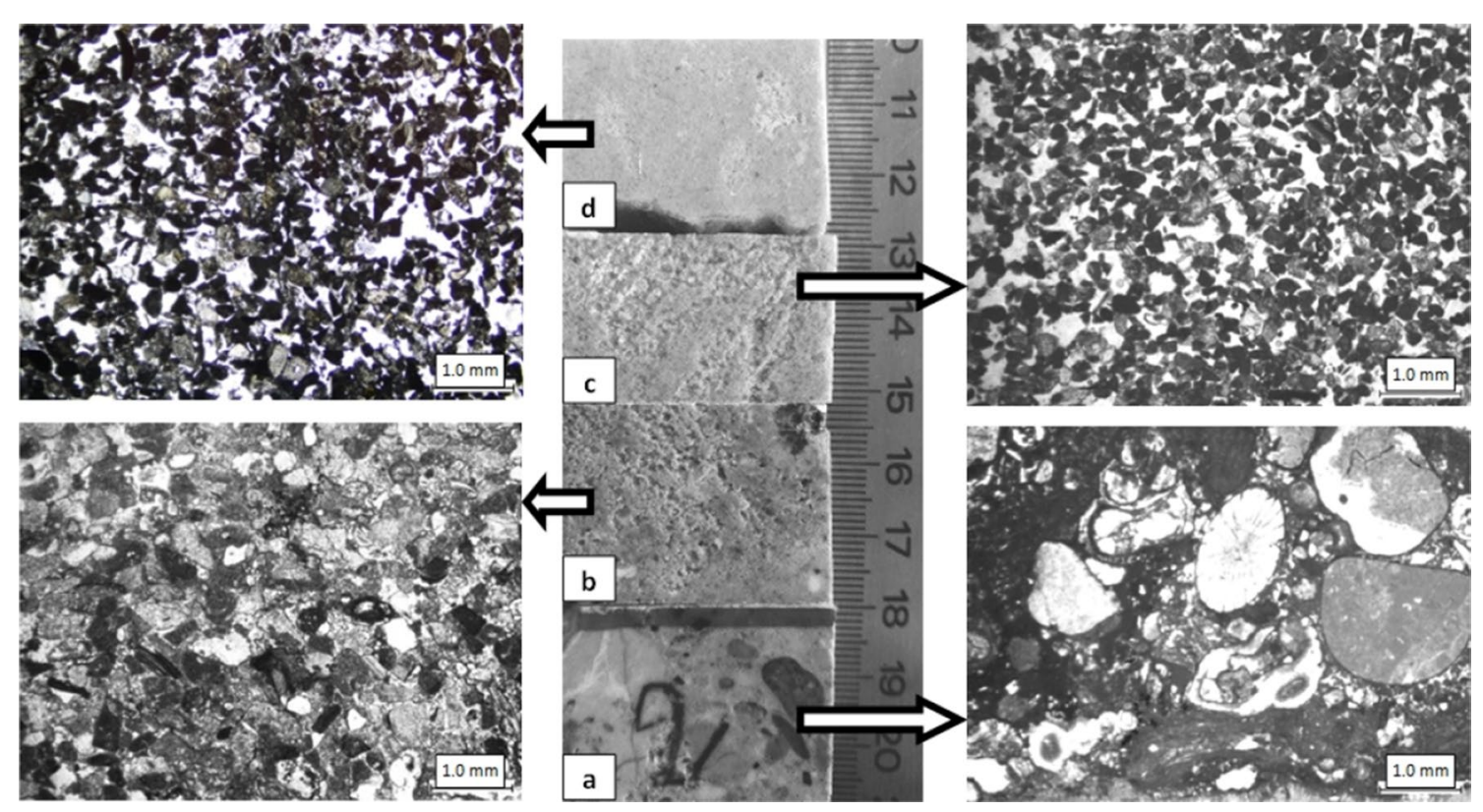

Fig. 5 Thin sections microphotographs in plane-polarized light and polished slabs of the lithofacies cropping out along the sides of Gravina di Petruscio: (a) rudstone; (b) coarse grainstone; (c) medium grainstone; (d) medium-fine grainstone 
mud exists in these materials. Instead, the amount of calcite cement is rather low for the medium and medium-fine grainstones and is limited to a border of finely crystalline calcite on the grain edge and pore-space perimeter, covered only in some places by lengthened crystals and microcrystals with a scalenohedronic or rhombohedral form (dog tooth cement). This cement constitutes manly a meniscus of calcite cement (early-stage cement) at grain contacts and around bioclasts. The coarse grainstones and rudstones also show late stage cement (sparry calcite), which partially or totally fills pore spaces. It consists of coarse-grained crystals of drusy or blocky calcite without a preferred orientation, which is typical of the calcarenite types characterized by more overall strength.

On the basis of Choquette and Pray's (1970) classification scheme, in all the calcarenite types the greatest contribution to the total porosity is provided by the primary intergranular porosity. Intragranular and moldic porosity provide a minor contribution and occur especially in the coarse grainstones. Moreover, all the calcarenite types reveal high total porosity constituted almost entirely or totally by intercommunicating pore spaces.

The morphology of the valley consists of 2 branches about $1 \mathrm{~km}$ long, from 270 to $200 \mathrm{~m}$ above sea level, that join in a single branch about $3 \mathrm{~km}$ long with a $\mathrm{N}-\mathrm{S}$ direction, and are at an elevation of 200 to $70 \mathrm{~m}$ above sea level. The valley is from 20 to $355 \mathrm{~m}$ wide and up to $45 \mathrm{~m}$ deep. The wider stretch corresponds to the rupestrian settlement, where over time the processes of slope retreat were more frequent. The cross section has a "U" shape, with five visible fluvial terraces on both sides (although other terraces might be covered by the vegetation located on the bottom of the valley), from $10 \mathrm{~m}$ to less than $2 \mathrm{~m}$ wide, connected by sub-vertical or overhanging faces from $2 \mathrm{~m}$ up to $15 \mathrm{~m}$ high. Epigeal karst forms, such as corrosion voids and cavities, caused by the dissolution of carbonate rocks by water containing dissolved carbon dioxide, are visible on the top surface. Although gravine and lame generally act as water flow channels only during and immediately after heavy rains, Gravina di Petruscio is permanently fed by depurated waste water coming from the residential center of Mottola.

\section{Geostructural and geomechanical surveys}

According to the ISRM recommendations (ISRM, 1978), traditional geostructural and geomechanical surveys were performed along the steep scarps and flat or gently sloping terraces to classify the rock mass and build the geomechanical model for predicting and assessing the instability potential, and failure types of the slopes and caves (Andriani and Parise 2015). In the first step, the main aim was to collect all the geometrical parameters regarding rock masses cropping out at the site and their discontinuity network. Both scanline and window mapping techniques were adopted for 11 measurement stations (at distances ranging from 20 to $200 \mathrm{~m}$ ), located on both the sides of the valley and on the alluvial terraces and inside caves which were accessible. In particular, $10 \mathrm{~m}$ scanlines and $10 \mathrm{~m}$ square windows were used for performing a 3-D geomechanical model and obtaining useful data for kinematic analysis of rock slopes by means of Goodman's graphical approach (Goodman and Shi 1985). The surveys were intensified in the rupestrian village, which is the part of the gravina of greater historical interest and frequented by tourists. For each discontinuity intersecting the scanlines, a quantitative description was obtained by direct inspection of orientation, spacing, shape, opening, continuity, roughness and filling. The structural features of the rock mass and the orientation of the discontinuities detected along the slopes were reported on stereographic diagrams using the Rocscience's Dips 7.0 software (2016) by tracing the planes on equatorial reticles (Schmidt nets) with equatorial projection (southern hemisphere). The graphic elaborations (Fig. 6) show the distribution of the poles and planes relative to the main joint families $(\mathrm{J} 1, \mathrm{~J} 2, \mathrm{~J} 3)$ on the west and east slopes, the bedding planes ( $\mathrm{S} 0)$ and the dip direction of the slopes are also reported. Two major $(\mathrm{J} 1, \mathrm{~J} 2)$ and two minor (J3, S0) discontinuity sets were identified in the Gravina di Petruscio area in three distinct structural fracture domains generally associated with the tectonic and geomorphic evolution of the study area. The orientation details and relative weight of the sets identified from the field measurements are summarized in Fig. 6.

On the basis of their orientation and persistence, the discontinuities belonging to set $\mathrm{J} 1$ represent the main failure surfaces along the sides of the valley; they are tensile fractures (release joints) that typically develop parallel to the natural slopes. We cannot ignore the possibility that release stress states may have occurred along pre-existing tectonic discontinuities. On both sides of the gravina, the joints of set J1 strike N-S and dip in close relationship with the geometry of the slope faces. Generally, on both sides the release joints are mainly subvertical or steeply dipping towards the valley axis. The $\mathrm{J} 2$ and $\mathrm{J} 3$ joints instead appear to be associated only to faults or fractures related to regional tectonic activities due to their extension and attitude. $\mathrm{J} 1$ and $\mathrm{J} 2 \mathrm{con}$ trol shapes and sizes of the rock blocks, which in part are unstable. According to Palmström (1995, 2001), based on the spacing of discontinuity sets $(1.75 \mathrm{~m}$ for $\mathrm{J} 1,1.00 \mathrm{~m}$ for $\mathrm{J} 2$ and $2.10 \mathrm{~m}$ for $\mathrm{J} 3)$, the volumetric joint count $\left(J_{\mathrm{V}}\right)$, block volume $\left(V_{\mathrm{B}}\right)$ and block shape factor $(\beta)$ were calculated as, $J_{\mathrm{V}}=2.05, V_{\mathrm{B}}=7.36 \mathrm{~m}^{3}, \beta=31.53$.

Thus, with the results of the geomechanical and geostructural surveys it is possible to assert that the rock mass cropping out along the sides of Gravina di Petruscio is made up of prismatic blocks rarely tabular, whose volumes vary between 3 and $15 \mathrm{~m}^{3}$. Albeit, on occasion it is possible to 
Fig. 6 On the left, best-fit great circles and poles for the main discontinuity sets detected on the west and east slopes of Gravina di Petruscio (lowerhemisphere Schmidt equal-area stereographic projections). On the right, discontinuity orientation and weight (mean values)
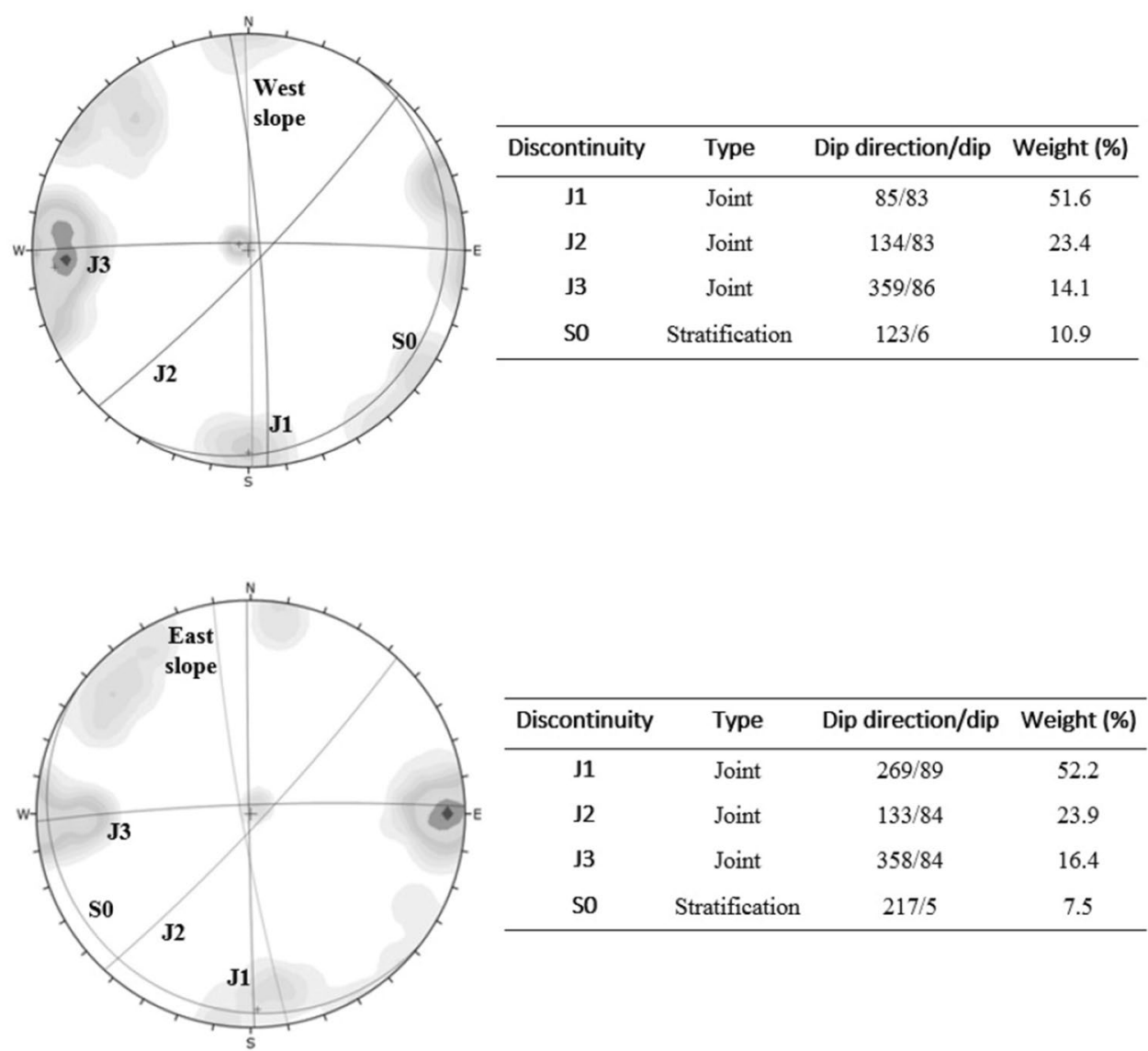

\begin{tabular}{cccc}
\hline Discontinuity & Type & Dip direction/dip & Weight (\%) \\
\hline J1 & Joint & $269 / 89$ & 52.2 \\
J2 & Joint & $133 / 84$ & 23.9 \\
J3 & Joint & $358 / 84$ & 16.4 \\
S0 & Stratification & $217 / 5$ & 7.5 \\
\hline
\end{tabular}

detect the presence of collapsed blocks whose size is smaller or larger than that calculated above with the Palmström's method. According to the GSI classification system (Marinos and Hoek 2000; Hoek and Brown 2019) a Geological Strength Index falling in the range 45-65, with a modal value of 53 , was assigned to the calcarenite rock masses cropping out in the study site.

\section{Instability mechanisms of the slopes and caves}

Failures observed during the field work for the surveys in Gravina di Petruscio can be grouped into two categories; (1) those that affect the slopes and (2) those that affect the caves. Both slopes of the gravina were affected by planar slides, wedge slides, direct toppling and falls (Fig. 7) (Cruden and Varnes 1996; Hungr et al. 2014). The failure mechanisms affecting the caves were observed to be related to thinning by spalling, crushing of pillars and partial or total collapse of cave roofs under flexural stress (Fig. 8). Moreover, the slope retreat processes, in places, involved the caves whose access is located on the sub-horizontal shelves of the terraces.

Regarding the valley sides, planar slides mostly occur along linear sliding discontinuity surfaces with the same orientation as J1 (Fig. 7a). In addition, direct toppling failures involve cubic and prismatic blocks, determined by $\mathrm{J} 1$,
J3 and S0, with a detachment surface that strikes approximately parallel to the slope face and dips steeply into the face (Fig. 7b). Undercutting of the slopes, due to differential weathering and erosion of sub-horizontal layers or banks, induces falls of overhanging blocks (Fig. 7c). Wedge sliding failures (Fig. 7d) involve pentahedral (5-sided) rock blocks generally defined by two intersecting discontinuities (two $\mathrm{J} 3$ or one $\mathrm{J} 2$ and one $\mathrm{J} 3$ in types showing opposed dip directions) oriented approximately perpendicular to the strike of the slope and a tension crack which strikes parallel to the slope face (J1). Although most of these slope instability mechanisms affect the older and higher terraces, as generally happens in the geomorphic evolution of a natural valley, the distributions of the different modes of failure depend on a combination of predisposing and triggering factors and spatial distribution of these factors, including structural and textural features which can locally influence the large-scale rock mass behavior. Abrupt falls of rock blocks detached from the steep slopes between terraces of different elevation are the main type of downslope movements by a significant margin of occurrence. A sequence of subhorizontal beds and banks characterized by an alternation of poorly cemented calcarenites (medium-fine grainstones) with tightly cemented calcarenites (coarse grainstones and rudstones) favored the presence of protruding blocks along 
Fig. 7 Examples of local failure mechanisms along the slopes of Gravina di Petruscio. a planar slidings; (b) direct topplings; (c) falling of overhanging rock blocks; (d) wedge slidings
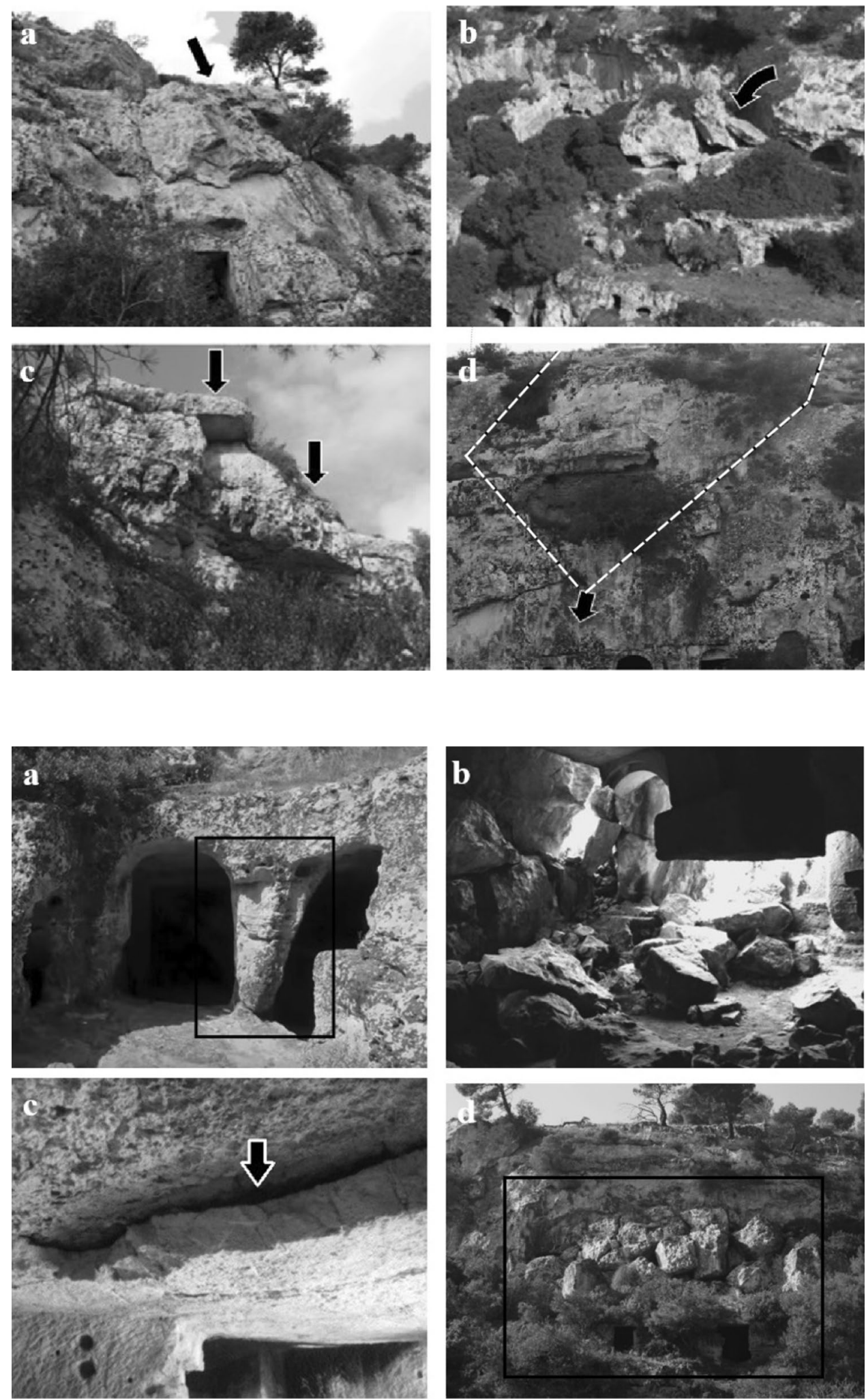

Fig. 8 Impact of human-made activity in Gravina di Petruscio. a pillar thinning by spalling; (b) block falls inside Cattedrale di Petruscio; (c) roof bending in an anthropogenic hypogeum; (d) rock block falls in correspondence of anthropogenic hypogea the slopes due to undercutting by weathering, erosion and, in places, human-induced landscape changes. As a result, unsupported rock blocks can move downward detaching from the slopes along pre-existing subvertical tension cracks subparallel to the free surfaces. Some blocks fall and rest upon the terrace below, while others reach the bottom of the valley by rolling or bouncing. Thus, continuous and repeated slope retreat processes are frequently abrupt and triggered by 
heavy rains or earthquakes, but always strongly linked to the strength loss of the outcropping material both for imbibition and creep (Ciantia et al. 2015; Andriani et al. 2019).

The subsequent result is the presence of damages and effects of static instability of the underground cavities due to overloads, leading to pillar thinning by spalling (Fig. 8a), block falls resulting from the failure of load bearing walls (Fig. 8b), roof bending with partial detachment along bedding planes (Fig. 8c) and block falls along the slope sides due to anthropogenic activity (Fig. 8d).

\section{Discussion}

An effective and exhaustive key of reading that can supply a correct and detailed assessment of the geohazards affecting Gravina of Petruscio cannot prescind from a holistic analysis of all the factors up to here considered. Field surveying data, genesis and local scale geologic interpretation, geostuctural and geomechanical reconstruction, classification and characterization of mass movement occurrences, and petrophysical description by means of a comprehensive approach allowed us to define predisposing factors and potential susceptibility to different geohazard problems for the study area. In broad outline, the case study of Gravina di Petruscio illustrates what is, in substance, the hazard condition which affects the Apulian gravine. In fact, floods and slope failure mechanisms, for the most part attributable to landslides, are common for all the valleys located in the Arco Ionico Tarantino subregion. In particular, for Gravina di Petruscio, we have to also consider other long-term processes which are closely affected by the peculiar geologic constraints and thus related, for some of them, to the main processes mentioned above. To reiterate, these processes are, (i) karst dissolution of the carbonate rocks which can develop into underground cavities and produce sudden collapses of the ground surface and sinkholes; (ii) weathering and fluidization of the weakly cemented and loosely packed calcarenite layers by groundwater seepage through them causing instability to overlying rock strata; (iii) creep behavior of the outcropping material; (iv) progression of rock weakening due to saturation. Regarding the latter, Apulian calcarenites are characterised by a mechanical ductile-brittle fracture mode transition strongly influenced by different saturation levels resulting in behavior that is affected by the presence of water in the pores, with strength and stiffness that significantly decrease in the transition from dry to saturated conditions (Andriani et al. 2019). It follows that the post-peak or post-failure characteristics of the different rock facies are different with a brittle behavior for dry material and a pseudo-ductile or ductile behavior for saturated material. Times and modes of saturation processes are strictly linked to structural and textural features of the rock masses.
Considering the various theories of the genesis of lame and gravine, it is possible to hypothesize the fundamental role of (i) the geostructural setting, which controlled and conditioned the water processes lato sensu, and (ii) the combined effects of down cutting and tectonic uplift. In particular, the geostructural and geomechanical surveys suggest that Gravina di Petruscio may be developed along a transpressional sinistral fault. This resulted in a state of stress and strain concentrated around the intersection between the principal and secondary branches of the valley (Fig. 9) and is due to a tip damage zone (Kim et al. 2004). The mean rates of valley deepening and widening were controlled by the bedrock uplift and sea-level changes of the area, starting from the middle Pleistocene.

Thus, the morphologic evolution of Gravina di Petruscio was conditioned by many factors acting in concert, although at different times. The actual morphology is in fact the result of the action of runoff and infiltration waters (mainly hydraulic and solution in types), and gravity-controlled processes, in turn influenced by human impact, karst features and other factors such as the loss of strength for the outcropping material both for imbibition and creep (Ciantia et al. 2015; Andriani et al. 2019). Continuous and repeated slope retreat processes are frequently abrupt and triggered by natural episodic events such as heavy rains or earthquakes. In this regard, the climate in Apulia is typically Mediterranean and semi-arid with a mean annual rainfall of about $600 \mathrm{~mm}$ and a mean annual temperature of about $15.5^{\circ} \mathrm{C}$. In the last 50 years, due to global warming, a decreasing annual trend in precipitation and rainfall intensity was observed, but, at the same time, more extreme rainfall events, which are concentrated in certain periods of the year, with longer intervals between events, have occurred (EEA, 2008). The effects of climate change led to an increase in occurrence of mass movements over time, which affected the stability of natural and engineered slopes (Gariano and Guzzetti 2016). Moreover, although central Apulia is considered essentially aseismic, low-energy seismic activity linked to tensional stresses affecting the upper crust creates conditions facilitating the release of seismic energy (Pierri et al. 2003). Thus, the Murge area is subjected to a tensional regime associated to the buckling of the Apulian plate caused by the interaction between the Apennine orogenic belt and the Adriatic foreland. These tectonic processes cause a greater energetic release in the border area between the Murge area and the Bradanic Foredeep, where Gravina di Petruscio is located. As a result of the tectonic forces described, it can be deduced that the reactivation of local tectonic structures, although characteristically associated with low magnitude energy release, can influence the stability of Gravina di Petruscio.

Furthermore, a higher slope retreat rate was observed in the tip damage zones of the gravina, where the stress and strain levels are higher, and in the areas more affected by 
Fig. 9 Transpressional sinistral fault on which Gravina di Petruscio is considered to be formed. The solid and the dashed segments mark, respectively, the primary fault and minor order discontinuities. Intersections between the two segments represent two tip damage zones (base map from https ://www.sit.puglia.it/; modified)

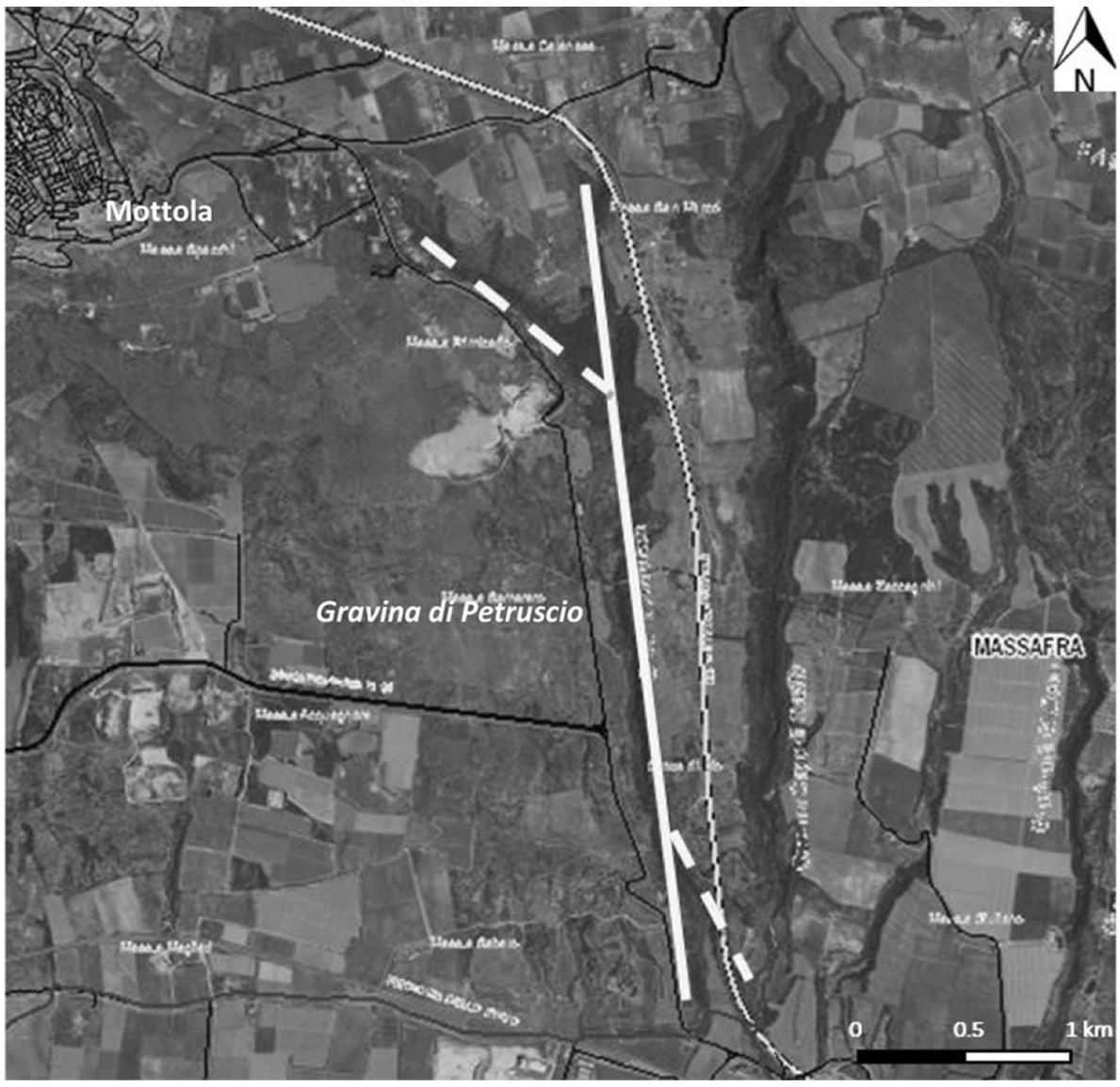

human impact, in correspondence with the medieval rupestrian settlement (Fig. 8). In fact, during the Middle Ages, man built inhabitable cavities digging in the softer levels of the calcarenite outcrops. They did so, however, without an appropriate construction method, correct sizing of rooms, load bearing walls and pillars, and without knowledge of the relationship of changes in the in-situ stress state due to the introduction of underground openings and mechanical behavior of the material, over time. Therefore, slow deformation for creep resulting from constant long-term loads and water infiltration were, over time, the main cause of reduction in rock mass strength.

Although significant mass movements have already occurred repeatedly, many warning signs of potential failure were recognized from observations in the field. And it is no accident that recent occasional occurrence of limited mass movements may have been caused by exceptional amounts of rainfall in a very short time as well as inertial forces induced by seismic shaking. Unfortunately, we cannot ignore that other failure mechanisms can occur triggered solely by irresponsible human behaviour. In this context, existing small infrastructure works in the gravina appear to be inappropriate remediation measures to inhibit the slope-failure susceptibility of the entire area. Thus, natural and human-induced hazard mitigation and preservation strategies for Gravina di Petruscio, as well as the other the Apulian karst valleys, require not only a detailed knowledge of the geological and structural setting, rock mass properties, influence of water and other external forces, but also that of the cave environment, including speleogenesis, pattern and morphology of karst passages, and historic and archaeological evidence for defining human impact in the course of time (Brinkmann and Parise 2012; Carlà et al. 2017). In this context, a multidisciplinary approach is needed for an integrated and sustainable management of these complex landscape systems in which both the natural environment and cultural heritage have to be monitored and protected.

After understanding failure mechanisms together with their predisposing and triggering factors, the next step must be the implementation of an engineering geology mapping project at a scale useful for planning and decision-making $(<1: 5,000)$. This project must be based on a complete and detailed geohazard assessment which requires both traditional methods, as has been pointed out in this work, as well as new techniques. Several of the latter include, but are not limited to, such techniques as use of geographic information systems (GIS) (Lee 2007), UAV (Unmanned Aerial Vehicles) and remote sensing (Mantovani et al. 1996; Casagli et al. 2016). It should be noted that detection, inventory and mapping of landslides or other failure mechanisms are 
difficult and time consuming processes due to the quality of the available data linked to the limited site accessibility, dense vegetation and influence of human activities. Integrated approaches for the stability assessment of slopes and caves, including in situ specific geostructural and geomechanical surveys, three-dimensional UAV-based photogrammetric structural models, laboratory geotechnical tests and, 2- and 3-D finite element analysis (FEM), in addition to providing information about the most hazardous discontinuities affecting the site, allow for the creation of parametric analyses with qualitative and quantitative data on the potential failure mechanisms and the probabilities of the potential failure modes (Fazio et al. 2019).

The establishing of monitoring and early warning systems is the next step, and it is important especially for an area such as this where presently the only barrier to access is a metal fence that limits public access to the site. An automated and integrated control and alarm system can offer early warning in times of ground movement and allow the selection and design of physical measures for reducing the real and long-term hazards. Problems in choosing tools and methods for this purpose are due to the lack of understanding of failure conditions and modes, mechanical behaviour of rock masses in terms of distribution of stress and strain over time, and costs. Ground surface movements are related to displacement and strain rates of the outcropping materials and may develop abruptly or over long periods of time. These movements can show, at places, also accelerationdeceleration phases due to seasonal variations in water content, associated with rainfall periods and changes in groundwater level and infiltration, or seismic shaking and in response to anthropogenic influences (Preisig et al. 2016). Although displacement and strain rates are controlled by the rock structure, they generally can increase suddenly and becoming elevated just prior to failure when the calcarenites are saturated. Thus, site-specific monitoring techniques, including field observations, trigonometric methods, ground-based radar, terrestrial laser scanning (TLS), airborne LIDAR (aerial laser scanning) and geotechnical sensors must be accompanied by controlling surface water and groundwater drainage (Kliche 1999). Conservation and preservation of natural and historic features of this site must be the basic criterion for designing stabilization measures capable of preventing stability problems. Before choosing the right methods for solving these problems, it is necessary to define the purpose of slope or cave stabilization, verify the accessibility of the area and assess the financial resources for this scope. Removal of unstable and loosely held overhang blocks by digging or wedging is to be preferred over the trim blasting due to the mechanical features of the rock masses. Removal of trees with roots inside the discontinuities and hand scaling of loose small blocks can complete this phase. Rock reinforcement consisting of bolts, dowels, micropiles, resin anchor systems or simply injections of mortars or resins can be useful along the sides and in the caves, where anchored retaining walls and buttresses can complete the stabilization method adopted. Surface and subsurface drainage systems can reduce infiltration and erosion in and along a potentially unstable rock mass and thus hindering saturation of the material. Stabilization methods of rock faces involve the prevention of rock detachments by wire mesh/cable net systems used to apply active retention force to retain blocks up to $3 \mathrm{~m}^{3}$, although the visual impact of mesh or net systems makes them unsuitable for use on a site rich in natural and cultural heritage (Kliche 1999; Wyllie and Mah 2004; Fell et al. 2008).

\section{Conclusions}

Through a case study regarding a typical dry valley of the Murge karst landscape in Apulia (Southern Italy), this paper illustrates how a multidisciplinary approach is indispensable for a preliminary assessment of the natural and humaninduced geohazards affecting the stability of canyons, gorges or ravines. There are many factors controlling the instability processes and mechanisms along the sides of these valleys including the caves which are today considered historical and architectural heritage sites. In this specific case, new information on the genesis of Gravina di Petruscio also provided a key to understanding the different slope retreat rates along the valley. Thus, a qualitative description of the failure mechanisms observed during field surveys has been interpreted on the basis of human changes, geostructural setting and mechanical behaviour of the calcarenites cropping out along the sides of the valley. The description of predisposing and triggering factors has made it possible to assess all the natural and anthropogenic hazards and understand the potential geomorphologic evolution of the valley.

Thus, for this type of morphostructure, a multidisciplinary approach may help to define priorities for disaster prevention strategies and provide valuable data for further stability analysis and/or for designing engineering measures and control techniques. In addition to Gravina di Petruscio, other Apulian gravine are, unfortunately, affected by slope retreat and other instability mechanisms. Like Gravina di Petruscio, these gravine are also associated with natural caves and artificial hypogea. However, while Gravina di Petruscio is recognized as a site belonging to the Bronze Age or later, other sites are attributed to previous periods. Ancient cultural sites, rupestrian churches, human and animal shelters dug into the rock, together with the natural beauty of the area, make Gravina di Petruscio a site visited by a huge number of tourists from all over the world. Unfortunately, there is still little attention and limited money budgeted for the conservation and safeguard of these sites 
from various hazards. Although over the past decades, the outcomes of risk management strategies have improved significantly, experience shows that there have been many opportunities to protect natural and cultural heritage, minimizing damages and, losses of human lives and in economic activities, but often approaches, solutions and adopted measures have not been adequate for lack of programs based on a holistic diagnosis, in-depth knowledge and deep understanding of the problem.

Acknowledgements We would like to thank the reviewers for valuable and constructive comments and suggestions. Thanks are due to Michael Tarullo of Monmouth University and Domenico Liotta of University of Bari for helpful discussions about this paper. Financial support of this research has been provided by "Terre Nostre" Cultural Association of Mottola (Apulia, Italy). Work carried out within the framework of the project Interreg III A-“WET SYS B" 2000-2006 (responsible G.F. Andriani), with the financial contribution by the European Community. Many thanks to Arcogem S.r.l. and I Like Puglia S.r.l. for the collaboration in the realization of the documentary "La Gravina di Petruscio" (https://www.youtube.com/watch?v=2sb2nCq6M40) made with divulgation of scientific findings scope during the surveys carried out for this study.

Funding Open access funding provided by Università degli Studi di Bari Aldo Moro within the CRUI-CARE Agreement.

Open Access This article is licensed under a Creative Commons Attribution 4.0 International License, which permits use, sharing, adaptation, distribution and reproduction in any medium or format, as long as you give appropriate credit to the original author(s) and the source, provide a link to the Creative Commons licence, and indicate if changes were made. The images or other third party material in this article are included in the article's Creative Commons licence, unless indicated otherwise in a credit line to the material. If material is not included in the article's Creative Commons licence and your intended use is not permitted by statutory regulation or exceeds the permitted use, you will need to obtain permission directly from the copyright holder. To view a copy of this licence, visit http://creativecommons.org/licenses/by/4.0/.

\section{References}

Akdim B, Amyay M (1999) Environmental vulnerability and agriculture in the karstic domain: landscape indicators and cases in the Atlas Highlands, Morocco. Int J Speleol 28(b):119-138.

Andriani GF, Parise M (2015) On the applicability of geomechanical models for carbonate rock masses interested by karst processes. Environ Earth Sci 74(12):7813-7821

Andriani GF, Parise M (2017) Applying rock mass classifications to carbonate rocks for engineering purposes with a new approach using the rock engineering system. J Rock Mech Geotech Eng 9(2):364-369

Andriani GF, Walsh N (2003) Fabric, porosity and water permeability of calcarenites from Apulia (SE Italy) used as building and ornamental stone. Bull Eng Geol Environ 62:77-84

Andriani GF, Walsh N (2009) An example of the effects of anthropogenic changes on natural environment in the Apulian karst (southern Italy). Environ Geol 58(2):313-325
Andriani GF, Walsh N (2010) Petrophysical and mechanical properties of soft and porous building rocks used in Apulian monuments (south Italy). Geol Soc Lond Spec Publ 333:129-141

Andriani GF, Luparelli F, Quarto R (2013) Water infiltration in unsaturated calcarenites. Rendiconti Online Società Geologica Italiana 24:15-18

Andriani GF, Lollino P, Perrotti M, Fazio NL (2019) Incidence of saturation and fabric on the physical and mechanical behaviour of soft carbonate rocks. ARMA 19-A-2044-ARMA

Badino G (1995) Fisica del clima sotterraneo. Memorie dell'Istituto Italiano di Speleologia s. II, 7, 136 pp.

Baker V, Kochel RC, Laity JE, Howard AD (1990) Spring sapping and valley network development. Special Paper Geol Soc Am 252:235-265

Bates RL, Jackson JA (1987) Glossary of geology, 3rd edn. American Geological Institute, Alexandria, p 788

Belluomini G, Caldara M, Casini C, Cerasoli M, Mandra L, Mastronuzzi G, Palmentola G, Sansò P, Tuccimei P, Vesica PL (2002) The age of Late Pleistocene shorelines and tectonic activity of Taranto area, Southern Italy. Quatern Sci Rev 21:525-547

Boenzi F (2004) Gravine. Italia: Atlante dei tipi geografici dell'Istituto Geografico Militare. Tavola 20:164-166

Bonacci O (2004) Hazards caused by natural and anthropogenic changes of catchment area in karst. Nat Hazards Earth Syst Sci 4:655-661

Božić S, Tomić N (2015) Canyons and gorges as potential geotourism destinations in Serbia: comparative analysis from two perspectives-general geotourists' and pure geotourists'. Open Geosci 7(1):531-546

Brinkmann R, Parise M (2012) Karst environments: Problems, management, human impacts, and sustainability - an introduction to the special issue. J Cave Karst Stud 74:135-136

Burri E, Castiglioni B, Sauro U (1999) Agriculture, landscape and human impact in some karst areas of Italy. Int J Speleol 28(1):33-54

Calò F, Parise M (2006) Evaluating the human disturbance to karst environments in Southern Italy. Acta Carsol 35(2):47-56

Carlà T, Farina P, Intrieri E, Botsialas K, Casagli N (2017) On the monitoring and early-warning of brittle slope failures in hard rock masses: examples from an open-pit mine. Eng Geol 228:71-81

Casagli N, Cigna F, Bianchini S, Hölbling D, Füreder P, Righini G, Del Conte S, Friedl B, Schneiderbauer S, Iasio C, Vlcko J, Greif V, Proske H, Granica K, Falco S, Lozzi S, Mora O, Arnaud A, Novali F, Bianchi M (2016) Landslide mapping and monitoring by using radar and optical remote sensing: examples from the EC-FP7 project SAFER. Remote Sens Appl 4:92-108

Choquette PW, Pray LC (1970) Geologic nomenclature and classification of porosity in sedimentary carbonates. Am Asso Petrol Geol Bull 54:207-250

Ciantia MO, Castellanza R, Crosta GB, Hueckel T (2015) Effects of mineral suspension and dissolution on strength and compressibility of soft carbonate rocks. Eng Geol 184:1-18

Ciaranfi N, Pieri P, Ricchetti G (1988) Note alla carta geologica delle Murge e del Salento (Puglia centromeridionale). Mem Soc Geol It 41:449-460

Colamonico C (1953) Lame e gravine in Puglia. Le Vie d'Italia 11:704

Cruden DM, Varnes DJ (1996) Landslides types and processes. In: Turner AK, Schuster RL (eds) Landslides investigation and mitigation. Transportation research board, US National Research Council. Special Report 247, Washington, DC, Chapter 3, 36-75.

Rocscience Inc., 2016. Dips Version 7.0 - Graphical and Statistical Analysis of Orientation Data. www.rocscience.com, Toronto, Ontario, Canada.

Day MJ (2007) Natural and anthropogenic hazards in the karst of Jamaica. Geol Soc Lond Special Publ 279:173-184 
De Giorgi C (1884) Cenni di geografia fisica della Provincia di Lecce, Tip edn. Salentina, Lecce

De Waele J, Follesa R (2004) Human impact on karst: the example of Lusaka (Zambia). Int J Speleol 32:71-84

De Waele J, Gutiérrez F, Parise M, Plan L (2011) Geomorphology and natural hazards in karst areas: a review. Geomorphology 134:1-8

Delle Rose M, Parise M, Andriani GF (2007) Evaluating the impact of quarrying on karst aquifers of Salento (southern Italy). In: Parise M, Gunn J (eds) Natural and Anthropogenic hazards in karst areas: recognition, analysis and mitigation. Geological Society, London, Special Publications, v 279, pp 153-171.

Derricourt RM (1976) Retrogression rate of the victoria falls and the Batoka Gorge. Nature 264:23-25

Doğan U, Koçyiğit A (2018) Morphotectonic evolution of Maviboğaz canyon and Suğla polje, SW central Anatolia, Turkey. Geomorphology 306:13-27

Doglioni C, Mongelli F, Pieri P (1994) The Puglia uplift (SEItaly): an anomaly in the foreland of the Apenninic subduction due to buckling of a thick continental lithosphere. Tectonics 13:1309-1321

Dunne T (1990) Hydrology, mechanics, and geomorphic implications of erosion by subsurface flow. Geol Soc Am Spec Pap 252:1-28

EEA, 2008. Impacts of Europe's changing climate - an indicator-based assessment. European Environment Agency Report, 4, https:// www.eea.europa.eu/publications/eea_report_2008_4/.

Fazio NL, Perrotti M, Andriani GF, Mancini F, Rossi P, Castagnetti C, Lollino P (2019) A new methodological approach to assess the stability of discontinuous rocky cliffs using in-situ surveys supported by UAV-based techniques and 3-D finite element model: a case study. Eng Geol 260:105205. https://doi.org/10.1016/j.engge o.2019.105205

Fell R, Corominas J, Bonnard C, Cascini L, Leroi E, Savage WZ (2008) Guidelines for landslide susceptibility, hazard and risk zoning for land use planning. Eng Geol 102:85-98

Frumkin A (1999) Interaction between karst, water, and agriculture over the climatic gradient of Israel. Int J Speleol 28B(1):99-110

Gams I, Nicod J, Julian M, Anthony E, Sauro U (1993) Environmental change and human impacts on the Mediterranean karsts of France, Italy and the Dinaric region. CATENA 25:59-98

Gariano SL, Guzzetti F (2016) Landslides in a changing climate. Earth Sci Rev 162:227-252

Ginés Á (1999) Agriculture, grazing and land changes at the Serra de Tramuntana karstic mountains. Int J Speleol 28:5-14

Goodman RE, Shi GH (1985) Block theory and its applications to rock engineering. Prentice-Hall, Englewood Cliffs

Goudie AS (2004) Encyclopedia of geomorphology. Routledge, London

Gunn J (2007) Contributory area definition for groundwater source protection and hazard mitigation in carbonate aquifers. In: Parise M, Gunn J (eds) Natural and anthropogenic hazards in karst areas: recognition, analysis and Mitigation. Geol Soc Lond Special Publ 279:97-109.

Hagerty DJ (1991) Piping/sapping erosion. I: basic considerations. J Hydraulic Eng 117:8,991-1006.

Hoek E, Brown ET (2019) The Hoek-Brown failure criterion and GSI-2018 edition. J Rock Mech Geotech Eng 11(3):445-463

Hungr O, Leroueil S, Picarelli L (2014) The Varnes classification of landslide types, an update. Landslides 11:167-194

International Society for Rock Mechanics (ISRM) (1978) Suggested methods for the quantitative description of discontinuities in rock masses. Int J Rock Mech Min Sci Geomech Abstracts 15:319-368

ISRM (1978) Suggested methods for the quantitative description of discontinuities in rock masses. Int Soc Rock Mech Int J Rock Mech Min Sci Geomech Abstracts 15(6):319-368

Kacaroglu F (1999) Review of groundwater pollution and protection in karst areas: Water, Air, \& Soil Pollution [Water, Air, Soil Pollut.], vol. 113, no. 1-4, pp. 337-356, Jul 1999.
Kim Y-S, Peacock CP, Sanderson DJ (2004) Fault damage zones. J Struct Geol 26:503-517

Kliche CA (1999) Rock slope stability. In: society for mining, metallurgy, and exploration, 1-254.

Lacasse S, Nadim F (2009) Landslide risk assessment and mitigation strategy. In: Sassa K, Canuti P (eds) Landslides—disaster risk reduction. Springer, Berlin, Heidelberg, pp 31-61

Lee $S$ (2007) Landslide susceptibility mapping using an artificial neural network in the Gangneung area, Korea. Int J Remote Sens Int J Remote Sens 28:4763-4783

Li JJ, Chen FF, Fang XM, Zou SZ, Pan BT (1995) Uplift of QuinghaiXizang Plateau and global change. Lanzhou Univ. Press, Lanzhou, p 320

Lollino P, Andriani GF (2017) Role of brittle behaviour of soft calcarenites under low confinement: laboratory observations and numerical investigation. Rock Mech Rock Eng 50(7):1863-1882

Mantovani F, Soeters R, Van Westen CJ (1996) Remote sensing techniques for landslide studies and hazard zonation in Europe. Geomorphology 15:213-225

Marinos P, Hoek E (2000) GSI: a geologically friendly tool for rock mass strength estimation. Proc. GeoEng2000 Conference, Melbourne. 1422-1442.

Marković M, Pavlović R, Čupković T (2003) Geomorfologija (Geomorphology). Faculty of Mining and Geology, University of Belgrade, (in Serbian)

Mastronuzzi G (2010) Le gravine e le lame. Il patrimonio geologico della Puglia. Territori e geositi. Supplemento al numero 4/2010 di Geologia dell' ambiente, Sigea, 75-84.

Mastronuzzi G, Sansò P (2002) Pleistocene sea level changes, sapping processes and development of valleys network in Apulia region (southern Italy). Geomorphology 46:19-34

Neboit R (1975) Plateaux et collines de Lucanie orientale et des Pouilles. Étude morphologique. Libr. Honore Champion, 715 pp, Paris.

Nicod J, Julian M, Anthony E (1997) A historical review of mankarstrelationships: miscellaneous uses of karst and their impact. Rivista di Geografia Italiana 103:289-338

Palagiano C (1965) Sulle lame e gravine della Puglia. Annali Fac. Econ. Comm., n.s., 21, 357-386, Bari.

Palmström A (1995) RMi-a rock mass characterization system for rock engineering purposes. Ph.D. thesis, University of Oslo, Norway, $409 \mathrm{pp}$.

Palmström A (2001) Measurement and characterization of rock mass jointing. In: Sharma VK, Saxena KR (eds) In-situ characterization of rocks. Balkema, A.A, pp 49-97

Parenzan P (1988) Importanza ecologica delle gravine pugliesi. Thalassia Salentina 18:55-62

Parise M (2007) Pericolosità geomorfologica in ambiente carsico: le gravine dell'Arco Ionico Tarantino. Atti e Memorie Commissione Grotte "E. Boegan" 41:81-94.

Parise M (2008) Elementi di geomorfologia carsica della Puglia. Atti del $5^{\circ}$ Corso CNSS-SSI di III livello "Geomorfologia Carsica", 93-118.

Parise M (2011) Surface and subsurface karst geomorphology in the Murge (Apulia, Southern Italy). Acta Carsol 40(1):79-93

Parise M, Gunn J (eds) 2007. Natural and anthropogenic hazards in karst areas: Recognition, Analysis and Mitigation. Geological Society, London, Special Publications, 279

Parise M, Pascali V (2003) Surface and subsurface environmental degradation in the karst of Apulia (southern Italy). Environ Geol 44:247-256. https://doi.org/10.1007/s00254-003-0773-6

Parise M, Federico A, Delle Rose M, Sammarco M (2003) Karst terminology in Apulia (southern Italy). Acta Carsol 32(2):65-82

Pieri P (1980) Principali caratteri geologici e morfologici delle Murge. Murgia sotterranea. Boll Gruppo Speleo Martinense 2:13-19 
Pierri, P., Del Gaudio, V., Calcagnile, G., Venisti, V., 2003. Revisione della sismicità murgiana. GNGTS - Atti del $22^{\circ}$ Convegno Nazionale.

Preisig G, Eberhardt E, Smithyman M, Preh A, Bonzanigo L (2016) Hydromechanical rock mass fatigue in deep-seated landslides accompanying seasonal variations in pore pressures. Rock Mech Rock Eng 49:2333-2351

Rashleigh E (1935) Among the waterfalls of the world. Jarrold, London Ricchetti G, Ciaranfi N, Luperto SE, Monelli F, Pieri P (1988) Geodinamica ed evoluzione sedimentaria e tettonica dell'Avampaese Apulo. Mem Soc It 41:57-82

Rohlfs, G., 1976. Vocabolario dei dialetti salentini (Terra d'Otranto). I-III. Congedo ed., Galatina.

Sauro U (1993) Human impact on the karst of the Venetian Fore-Alps (Southern Alps, Northern Italy). Environ Geol 21(3):115-121

Sauro U (2006) Changes in the use of natural resources and human impact in the karst environment of the Venetian Prealps (Italy). Acta Carsologica 35(2):57-63

Scheidegger, A.E., Hantke, R., 1994. On the genesis of river gorges, Transactions, Japanese Geomorphological Union, 15(2), 91-110

Segre AG (1947) Aspetti antropici del fenomeno carsico nell'Italia peninsulare Memorie di Geografia Antropica. CNR, Roma

Serafini L, Di Giorgio A, (2018) The preservation of rupestrian churches. researchand experiences in Italy. In: Koui M, Zezza F, Kouis D (eds) 10th international symposium on the conservation of monuments in the Mediterranean Basin: Natural and Anthropogenic Hazards and Sustainable Preservation, 66, 611-622.

Smith DI (1993) The nature of karst aquifers and their susceptibility to pollution. In: Karst terrains. environmental changes and human impact, Catena, 25, 41-58.

Spizzico M, Lopez N, Sciannamblo D (2005) Analysis of the potential contamination riskof groundwater resources circulating in areas with anthropogenic activities. Nat Hazard Earth Syst Sci 5:109-116
Stokes M, Mather AE (2008) Active and passive tectonic controls for transverse drainage and river gorge development in a collisional mountain belt (Dades Gorges, High Atlas Mountains, Morocco). Geomorphology 102:2-20

Tinkler KJ, Pengelly JW, Parkins WG, Asselin G (1994) Postglacial recession of Niagara Falls in relation to the Great Lakes. Quatern Res 42:20-29

Tropeano, M., Sabato, L., 2000. Response of Plio-Pleistocene mixed bioclastic-lithoclastic temperate-water carbonate systems to forced regressions: the Calcarenite di Gravina formation, Puglia SE Italy. In: Hunt D, Gawthorpe RL (eds) Sedimentary Responses to Forced Regressions. Geol. Soc. of London, Spec. Publ. 172, pp. $217-243$.

Urich PB (2002) Land use in karst terrain: Review of impacts of primary activities on temperatekarst ecosystems. Sci Conservation 198:60

Van der Beek P, Pulford A, Braun J (2001) Cenozoic landscape development in the Blue Mountains (SE Australia): lithological and tectonic bcontrols on Rifted Margin Morphology. J Geol 109:35-56

Waltham T, Lu Z (2007) Natural and anthropogenic rock collapse over open caves. Geol Soc Lond Special Publ 279(1):13-21

White WB (1988) Geomorphology and hydrology of karst terrains. Oxford University Press, New York, p 464

Williams PW (1993) Karst Terrains, Environmental Changes and Human Impact. Cremingen-Destedt, Germany, Catena Supplement no. 25,268 pp.

Wyllie DC, Mah CW (2004) Rock slope engineering, civil and mining, 4th edn. Spon Press, Taylor \& Francis Group, New York, p 431

Publisher's Note Springer Nature remains neutral with regard to jurisdictional claims in published maps and institutional affiliations. 